Review Article

\title{
Seat belts and injury patterns: evolution and present perspectives
}

\author{
Ashis Banerjee \\ Accident and Emergency Department, Walsall General Hospital, Walsall, West Midlands WSI 3QY, UK.
}

\section{Introduction}

Seat belt legislation appears to have reduced mortality from, and the incidence of, serious head and facial injuries due to motor vehicle accidents.

The use of seat belts has, however, also modified injury patterns in car occupants involved in accidents. This review traces the introduction of seat belt legislation and delineates the types of injury which have been attributed to seat belt wearing.

\section{Historical aspects}

The need for passive restraints and alterations in car interior design was first noted by Straith. ${ }^{1}$ This was the result of his experience with facial injuries in unrestrained car drivers and front seat passengers. ${ }^{2}$

Seat belts in cars were introduced in the early 1950 s, following the example set by the airline industry. In the United Kingdom, the provision of front seat belts became a legal requirement for all cars registered from January 1, 1965 onwards. However, low compliance with the use of seat belts (in the range of $20-30 \%$ ) was the rule, despite an expensive Government-sponsored 'Clunk-Click' advertising programme.

Following Tourin and Garrett's study ${ }^{3}$ many papers attested to the efficacy of seat belt use. The first territory to make seat belt wearing compulsory for front seat passengers was the Australian state of Victoria, in December 1970. By the end of January 1972, the whole of Australia and New Zealand had followed suit.

While the medical profession in this country consistently advocated compulsory seat belt use, opponents of what some people considered an affront to personal liberty repeatedly thwarted the passage of

Correspondence: A. Banerjee, M.S., F.R.C.S., F.R.C.S. (Edin)

Accepted: 9 November 1988
Bills to make seat belt wearing compulsory, in 1973 , 1974, 1977 and $1979 .{ }^{4}$ Regulations making seat belt wearing compulsory in the United Kingdom for drivers of, and front seat passengers in, cars and light vans came into effect on January 31,1983 , the Bill responsible having become law on July 28,1981 . The success of this legislation in terms of improved compliance with use (over $90 \%$ ) and reduction in deaths and serious injuries led to ratification of the Bill after a three year trial period, on January 31, 1986.

As from October 1, 1986, all new cars registered in the United Kingdom are legally required to be fitted with rear seat belts as well. Unrestrained back seat passengers, especially children, are also recognized to be at risk of injury in deceleration accidents, ${ }^{5}$ and may be forcibly propelled within the car. A proposed Bill in Parliament will make it compulsory for children of 13 years of age or less and all adults who possess rear seat belts in their cars to wear them compulsorily. The need for restraining coach passengers is suggested on the basis of a study of injury patterns in coach crashes. ${ }^{6}$

A number of prospective studies, initiated since the enactment of seat belt legislation, both in Australia ${ }^{7} 11$ and the United Kingdom, ${ }^{12-16}$ have documented a decrease in mortality, hospitalization rates, and the incidence of serious head and facial injuries from car collisions involving frontal impact. A decrease in the incidence of dashboard injuries leading to fractures of the femur and patella has also been demonstrated.

Both retrospective and prospective studies of perforating eye injuries in Australia ${ }^{17}$ and the United Kingdom ${ }^{18-21}$ have shown a considerable decrease in their incidence following seat belt legislation. The concurrent introduction of laminated glass windscreens may, however, be partly responsible for this improvement. ${ }^{22}$

Initially, seat belts were either pure lap or diagonal belts, providing two point fixation only. However, the combined lap-diagonal belt is obligatory under the 1981 Transport Act. Indeed, a full harness system with four point anchorage may be preferable to prevent torsional injuries of the neck and jaw..$^{23.24}$

(C) The Fellowship of Postgraduate Medicine, 1989 


\section{Spinal injuries}

Injury to the spine has been reported to occur with the use of both two and three point fixation providing belts, and can involve the cervical, thoracic or lumbar spines.

Overall, a protective effect of the seat belt is demonstrable. ${ }^{25.26}$ One 15 year study from the Sheffield spinal injury unit shows that, of all motorists admitted with acute spinal injury, only one in every twelve had been wearing a seat belt when the accident occurred. The incidence of paraplegia has been lowered by seat belt use. ${ }^{26,27}$

Specific patterns of spinal injury have been repeatedly reported. The majority of early reports were of lumbar spine injuries in lap belt wearers.

Chance ${ }^{28}$ first described a horizontal splitting fracture of the lumbar vertebrae involving the spinous processes and neural arch, but he did not discuss the mechanism of injury. Howland et al. ${ }^{29}$ first reported the occurrence of a similar fracture in relation to lap seat belt use. They suggested that this injury was caused by hyperflexion of the lumbar spine over a fulcrum provided by the belt.

Smith and Kaufer ${ }^{30,31}$ analysed 24 lumbar spine injuries in lap seat belt wearers and demonstrated a type of injury involving osseous and/or ligamentous disruption of the posterior elements (i.e. posterior ligament and facet joint rupture) with longitudinal separation of these elements.

Similar injuries have been repeatedly encountered ${ }^{32-37}$ but it is likely that their incidence is likely to be less now that lap-diagonal belts are used. The injury mechanism has been described as a flexiondistraction stress produced by jack-knifing of the torso over the lap belt, unaccompanied by rotation. ${ }^{38}$ This is in contrast to the more common flexion-compression injuries of the lumbar spine producing anterior wedging of the vertebral bodies.

Decapitating injuries of the neck were reported from Sweden when a diagonal belt was used by itself. ${ }^{39}$ Decapitation occurred when the driver's chin caught on the belt during ejection from the car.

At present, hyperextension injuries of the neck leading to neck sprains are the commonest form of spinal injury in seat belted individuals. ${ }^{40}$ Macnab $^{41.42}$ demonstrated that neck hyperextension in deceleration accidents is only opposed by contact of the occiput on the posterior chest wall. A constellation of anterior neck soft tissue injuries was demonstrated by him in experimental hyperextension injuries in anaesthetized monkeys. Lack of effectiveness of head restraints is no doubt a contributory factor in human injuries. ${ }^{43}$

Cervical vertebral fractures are due to flexion stresses in frontal impact collisions with the diagonal belt acting as a fulcrum. Anterior neck bruising produced by the belt is often associated..$^{44}$ Oblique hyperflexion can produce cervico-thoracic transverse process fractures. ${ }^{45}$ Epstein et al. ${ }^{46}$ have reported on $\varrho$ cervical spine fractures related to combined lap- $\frac{\bar{D}}{\infty}$ diagonal belts, indicating lack of protection with three $\cong$ point fixation.

\section{Abdominal injuries}

Abdominal injuries are caused by the restraining and $\vec{\Phi}$ compressive effects of the lap belt in deceleration accidents. The abdominal wall, intra-abdominal hol-e low or solid viscera, diaphragm, and major blood $\overrightarrow{0}$ vessels can be injured singly or in various combin- $\overrightarrow{-}$ ations.

The first report of intra-abdominal injury att-ributable to a seat belt was by Kulowski and Root, ${ }^{4} \frac{6}{3}$ who described a case of terminal ileal contusion.

Abdominal wall injury may present as haematomas ${ }^{\circ}$ in the rectus sheath, or as disruption ${ }^{48}$ or avulsion ${ }^{49} /$ injuries of the musculature. Delayed ventral hernia ${ }_{-}^{N}$ formation at the site of injury has also been reported. ${ }^{50} \varnothing$ By far the commonest form of parietal injury consistso of abrasions, contusions, ecchymoses and friction? burns at the site of the seat belt. This finding has been $>$

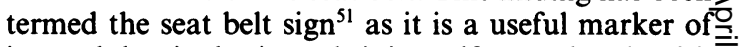
intra-abdominal visceral injury if associated with $\overrightarrow{\vec{\theta}}$ incorrect placement of the belt (indicated by a high, i\&. supra-umbilical position of the skin changes). The sign. may be obscured if a heavy overcoat is worn. ${ }^{52}$.

Stomach injuries are relatively rare as the stomach thick walled and partly protected by the costal margin, but it is vulnerable in deceleration injuries by virtue of its relative fixity at both proximal and distal ends. ${ }^{53} \stackrel{\varrho}{\varrho}$ Rupture has been reported in the distended organ after $\overrightarrow{\overrightarrow{0}}$ a heavy meal. ${ }^{54}$

Seat belt-related small bowel trauma has been classified into three major groups, based on a study of: 32 patients, by Christophi et al..$^{55}$ (a) Deceleration injuries causing shearing forces, maximally at junc- 3 . tions of relatively fixed and relatively mobile parts. In' this group complete transections of the first $20 \mathrm{~cm}$ of . the proximal jejunum, radial mesenteric tears, avul-oิ sions of the transverse colon or splenic flexure and splenic rupture were noted. (b) Crush injuries between을 the lap belt and vertebral column causing mesenteric $>$ haematomas, transverse mesenteric tears, aortic and으․ vena caval injury, caecal contusion and Chance fractures of the lumbar spine. (c) Functional closed loop. obstructions with single or multiple blow-out perfor- $N$ ations of the antimesenteric border of the gut due to raised intra-luminal pressure.

Delay in recognition of small bowel injuries hase been reported by several authors. ${ }^{56,57}$ This may be due $\frac{}{\mathbb{}}$ in part to attributing signs of intra-abdominal injury $\stackrel{\oplus}{+}$ to co-existent abdominal wall injury. 
Delay in presentation of gut injuries may be due to: (a) late-onset perforation secondary to ischaemic necrosis following intramural haematoma formation or mesenteric tears or haematomas; ${ }^{58}$ (b) the development of ischaemic small bowel strictures ${ }^{59-61}$ which may mimic inflammatory bowel disease. ${ }^{62}$

Gall bladder rupture is possible with tense distension of the organ, which may be produced by alcohol ingestion. ${ }^{63}$ Hepatic injuries may lead to parenchymal tears and haematoma formation. Organization of haematoma has been reported to cause intrahepatic common bile duct obstruction. ${ }^{64}$

Isolated pancreatic damage in upper abdominal crush injuries has been recorded ${ }^{65}$ as have combined pancreatico-duodenal injuries. Diagnosis can be difficult and mortality is high. Pancreatic injury has been reported to cause metastatic fat necrosis. ${ }^{66}$

Injury to abdominal stomas is possible, causing mucocutaneous injuries with bleeding, ${ }^{67}$ but the presence of a stoma on the abdominal wall does not contraindicate seat belt wearing. ${ }^{68}$ Any likely complications are amenable to minor surgical procedures.

Aortic trauma due to seat belts was first reported by Campbell and Austin. ${ }^{69}$ Aortic injuries are characterized by intimal transection and dissection, causing luminal occlusion, thrombosis and lower limb ischaemia. This is believed to be the result of longitudinal tension in the aorta from simultaneous caudal and cranial stretch. Injuries have been described in isolation ${ }^{70}$ or in combination with other visceral trauma ${ }^{60,71}$ Arterial emboli have been noted to be dislodged from pre-existing thrombus. ${ }^{72}$

Other major vessels in the abdomen can also be injured. A case of seat-belt related portal vein thrombosis associated with organized mesenteric haematoma has thus been described. ${ }^{73}$

Although at the onset there was some doubt as to the advisability of seat belt use in pregnancy, experimental studies in baboons purported to show increased fetal survival in front end collisions if seat belts were worn. ${ }^{74}$ Although cases of uterine rupture in association with lap belt wearing have been described, ${ }^{75-77}$ it has been stressed that these occurred when the belt was incorrectly worn, the lap component being higher than the iliac crests. Other possible injuries include abruptio placentae, abortion, premature labour and premature rupture of membranes. ${ }^{77}$ These complications are the exception and indeed many pregnant women involved in car crashes owe their lives to the seat belt. ${ }^{78,79}$

\section{Chest and neck injuries}

Chest and neck injury is produced by the restraining influence of the diagonal component of the seat belt. Soft tissue injuries of the chest wall occur predominantly on the side of the belt and hence occur on different sides in drivers and passengers. These take the form of abrasions, ecchymoses and friction burns, producing an imprint of the belt.

Rib fractures may also be produced by seat belt compression. While there seems to be no reduction in the incidence of rib fractures, the severity and number of rib fractures sustained is diminished as compared with unbelted individuals. ${ }^{80.81}$

The association of seat belt wearing with sternal fractures is well known. ${ }^{82}$ A proportional increase in incidence of $100 \%$ in drivers and $150 \%$ in front seat passengers has been noted since the enactment of seat belt legislation in a multicentre study. ${ }^{12}$ Sternal fractures may be associated with myocardial contusion ${ }^{83}$ which is often clinically silent. ${ }^{84}$

Sternal fractures are usually undisplaced. Where displaced and a step deformity exists at the fracture site, open reduction and wire fixation of the fragments is needed. ${ }^{85}$

Trauma to the female breast can be produced by a combination of compression and shearing stress produced by the seat belt. Subcutaneous rupture of breast tissue has been reported; ${ }^{86}$ in the lactating breast this produces lactiferous duct avulsion and recurrent engorgement of the breast with milk. Residual grooves and other contour deformities may occur which may need plastic surgical correction. The presence of a persistent mass noted after injury must always be taken seriously, as trauma may draw attention to an unsuspected carcinoma. In a series of 6 cases of breast lumps attributed to seat belt trauma, 3 were found to be carcinomas on histological examination. ${ }^{87}$ Biopsy is therefore mandatory in the presence of a palpable mass. Other injuries reported include massive haematoma in the breast ${ }^{88}$ and rupture of silicone prostheses with silicone extravasation. ${ }^{89}$

Repeated micro-trauma at the site of a pacemaker pocket may cause local discomfort. ${ }^{90}$

Raised intra-thoracic pressure due to seat belt induced compression has been reported to cause acute visual loss related to traumatic retinopathy of Purtscher. $^{91,92}$

Mediastinal widening on chest X-ray in the presence of a seat belt injury may indicate aortic rupture or other major vessel injury. ${ }^{93}$ Confirmation of the diagnosis by aortography or computed tomographic scanning and surgical repair are necessary.

\section{Conclusions}

The compulsory wearing of seat belts has undoubtedly reduced mortality from, and the incidence of, serious head and facial injuries from motor vehicle accidents. However, seat belts in their present form appear to be associated with an increased incidence of neck sprains, 
chest wall injuries and torsional injuries of the head and neck.

Further improvements in design and improved adjustability of seat belts, coupled with compulsory wearing of seat belts by rear seat passengers is awaited.

\section{Acknowledgements}

I wish to thank Miss Sheila Christian, Consultant in Accident and Emergency at Wexham Park Hospital, Slough, for reading through and making useful suggestions in connection with the preparation of this paper. Any conclusions drawn from the literature do not necessarily reflect her own views.

\section{References}

1. Straith, C.L. Automobile injuries. JAMA 1937, 109: 940-945.

2. Straith, C.L. Management of facial injuries caused by motor accidents. JAMA 1937, 108: 101-105.

3. Tourin, B. \& Garrett, J.W. Safety belt effectiveness in rural California automotive accidents. Automotive Crash Injury Research of Cornell University, New York, 1960.

4. Personal liberty versus common sense. (Leading article). Lancet, 1980, ii: 567-568.

5. Christian, M.S. Non-fatal injuries sustained by back seat passengers. Br Med J 1975, 1: 330-332.

6. Scammell, B.E. \& Clarke, N.M.P. The unrestrained coach passenger - an injury complex. Injury 1987, 18: $1-4$.

7. Trinca, G.W. \& Dooley, B.J. The effects of mandatory seat belt wearing on the mortality and pattern of injury of car occupants involved in motor vehicle crashes in Victoria. Med J Aust 1975, 1: 675-678.

8. Trinca, G.W., Dooley, B.J. The effects of seat belt legislation on road traffic injuries. Aust NZ J Surg 1977, 47: $150-155$.

9. McDermott, F.T. \& Hough, D.E. Reduction in road fatalities and injuries after legislation for compulsory wearing of seat belts: experience in Victoria and the rest of Australia. Br J Surg 1979, 66: 518-521.

10. McDermott, F. \& Hough, D. Vehicle-occupant fatalities after legislation for compulsory wearing of seat belts in Australia. Med J Aust 1979, 2: 571-575.

11. Petty, P.G. The influence of seat belt wearing on the incidence of severe head injury. Med J Aust 1975, 2: $768-769$.

12. Rutherford, W.H., Greenfield, T., Hayes, H.R.M. \& Nelson, J.K. The medical effects of seat belt legislation in the United Kingdom. DHSS (Office of the Chief Scientist). HMSO Research Report No. 13, 1985.

13. Rutherford, W.H. The medical effects of seat-belt legislation in the United Kingdom: a critical view of the findings. Arch Emerg Med 1985, 2: 221-223.

\section{Documentation in seat belt related trauma}

Type of seat belt worn

Direction and velocity of impact

State of interior of car and of windscreen

Site(s) of seat belt induced skin lesions

Site of spinal tenderness

Tenderness over sternum and ribs

\section{Desirable improvements}

Harness-type seat belts

Fully retractable seat belts

Adjustable head restraints

Compulsory rear seat belt wearing

Restraints for children adjusted for size and age Collapsible car interiors
14. Pye, G. \& Waters, E.A. Effect of seat belt legislation on injuries in road traffic accidents in Nottingham. $\mathrm{Br}$ Med $\mathrm{J}$ 1984, 228: 756-757.

15. Allen, M.J., Bodiwala, G.G. \& Barnes, M.R. The effect of seat belt legislation on injuries sustained by car occupants. Injury 1985, 16: 471-476.

16. Dreghorn, C.R. The effect of seat belt legislation on a district general hospital. Injury 1985, 16: 415-418.

17. Briner, A.M. Penetrating eye injuries associated wit motor vehicle accidents. Med J Aust 1976, 1: 912-916.

18. Vernon, S.A. \& Yorston, D.B. Incidence of ocula injuries from road traffic accidents after introduction of seat belt legislation. $J R$ Soc Med 1984, 77: 198-200.

19. Hall, N.F., Denning, A.M., Elkington, A.R. \& Cooper, P.J. The eye and the seat belt in Wessex. Br J Ophthalmol 1985, 69: 317-319.

20. Johnston, P.B. \& Armstrong, M.F.J. Eye injuries in Northern Ireland two years after seat belt legislation. $\mathrm{Br}$ J Ophthalmol 1986, 70: 460-462.

21. Cole, M.D., Clearkin, L., Dabbs, T. \& Smerdon, D. The seat belt law and after. $\mathrm{Br} J$ Ophthalmol 1987, 71: 436-440.

22. Keightley, S.J. Serious eye injury from windscreen contact. J R Soc Med 1983, 76: 911-916.

23. Campbell, H.E. And shoulder strap, too. Rocky Mountain Med J 1963, 60: 29.

24. Roydhouse, R.H. Torquing of neck and jaw due to belt restraint in whiplash-type accidents (letter). Lancet, 1985, i: 1341 .

25. Watson, N. Road traffic accidents, spinal injuries and seat belts. Paraplegia 1983, 21: 63-64.

26. Burke, D.C. Spinal cord injuries and seat belts. Med J Aust 1973, 2: $801-806$.

27. Holt, B.W. Spines and seat belts. Mechanisms of spinal injury in motor vehicle crashes. Med J Aust 1976, 2: 411-413.

28. Chance, G.Q. Note on a type of flexion fracture of the spine. Br J Radiol 1948, 21: 452-453. 
29. Howland, W.J., Curry, J.L. \& Buffington, C.B. Fulcrum fractures of the lumbar spine. Transverse fractures induced by an improperly placed seat belt. JAMA 1965 , 193: $240-241$.

30. Smith, W.S. \& Kaufer, H. A new pattern of spine injury associated with lap-type seat belts - A preliminary report. Univ Michigan Med Cent J 1957, 33: 99-104.

31. Smith, W.S. \& Kaufer, H. Patterns and mechanisms of lumbar injuries associated with lap seat belts. $J$ Bone Joint Surg (Am) 1969, 51: 239-254.

32. Huelke, D.F. \& Kaufer, H., Vertebral column injuries and seat belts. J Trauma, 1975, 15: 304-318.

33. Gumley, G., Taylor, T.K.F. \& Ryan, M.D. Distraction fractures of the lumbar spine. $J$ Bone Joint Surg $(\mathrm{Br})$ 1982, 64: 520-525.

34. Dehner, J.R. Seatbelt injuries of the spine and abdomen AJR 1971, 111: 833-843.

35. Greenbaum, E., Harris, L. \& Halloran, W.X. Flexion fracture of the lumbar spine due to lap-type seat belts. Calif Med 1970, 113: 74-75.

36. Friedman, M.M., Becker, L., Reichmister, J.P. \& Neviaser, J.S. Seat belt spinal fractures. Am Surg 1969, 35: 617-618.

37. Steckler, R.M., Epstein, J.A. \& Epstein, B.S. Seat belt trauma to the lumbar spine: An unusual manifestation of the seat belt syndrome. J Trauma 1969, 9: 508-512.

38. Rennie, W. \& Mitchell, N. Flexion distraction fractures of the thoracolumbar spine. $J$ Bone Joint Surg (Am) 1973, 55: 386.

39. Saldeen, T. Fatal neck injuries caused by use of diagonal seat belts. J Trauma 1967, 7: 856-862.

40. Deans, G.T., Magalliard, J.N., Kerr, M. \& Rutherford, W.H. Neck sprains - a major cause of disability following car accidents. Injury 1987, 18: 10-12.

41. Macnab, I. Acceleration injuries of the cervical spine $J$ Bone Joint Surg (Am) 1964, 46: 1797-1799.

42. Macnab, I. The whiplash syndrome. Orthop Clin N Am 1971, 2: 389.

43. Olney, D.B. \& Marsden, A.K. The effect of head restraints and seat belts on the incidence of neck injury in car accidents. Injury 1986, 17: 365-367.

44. Taylor, T.K.F., Nade, S. \& Bannister, J.H. Seat belt fracture of the cervical spine. J Bone Joint Surg (Br) 1976, 58: 328-331.

45. Arndt, R.D. Cervico-thoracic transverse process fracture further observations on the seat belt syndrome. $J$ Trauma 1975, 15: 600-602.

46. Epstein, B.S., Epstein, J.A. \& Jones, M.D. Lapsash 3 point seat-belt fractures of the cervical spine. Spine 1978, 3: $189-193$.

47. Kulowski, J. \& Root, W.B. Intra-abdominal injury from safety belt in auto accident. Report of a case. Arch Surg 1956, 73: 970-971.

48. Wagner, A.C. Disruption of abdominal wall musculature: Unusual feature of seat belt syndrome. $A J R$ 1979, 133: 753-754.

49. Payne, D.D., Resnicoff, S.A., States, J.D. \& Williams, J.S. Seatbelt abdominal wall muscular avulsion. $J$ Trauma 1973, 13: 262-267.

50. Hurwitt, E.S. \& Silver, C.E. Seat-belt hernia. JAMA 1965, 194: 2239-2241.
51. Doersch, K.B. \& Dozier, W.E. The seat belt syndrome. The seat belt sign, intestinal and mesenteric injuries. $\mathrm{Am}$ J Surg 1968, 116: 831-833.

52. Pedersen, S. \& Jansen, U. Intestinal lesions caused by incorrectly worn seat belts. Acta Chir Scand 1979, 145: 15- 18 .

53. Dajee, H. \& MacDonald, A.C. Gastric rupture due to seat belt injury. Br J Surg 1982, 69: 436.

54. Baker, A.R., Perry, E.P. \& Fossard, D.P. Traumatic rupture of the stomach due to a seat belt injury. Injury 1986, 17: 47-48.

55. Christophi, C., McDermott, F.T., McVey, I. \& Hughes, E.S.R. Seat-belt induced trauma to the small bowel. World J Surg 1985, 9: 794-797.

56. Snyder, C.C. Bowel injuries from automobile seat belts Am J Surg 1972, 123: 312-316.

57. Ritchie, JR, W.P., Ersek, R.A., Bunch, W.L., Simmons, R.L. Combined visceral and vertebral injuries from lap type seat belts. Surg Gynecol Obstet 1970,131: 431-435.

58. Blumenberg, R.M. The seat belt syndrome: sigmoid colon perforation. Ann Surg 1967, 165: 637-639.

59. Pohl, M.J. \& Cook, W.J. Small bowel stenosis after seat belt injury. Med J Aust 1980, 2: 156.

60. Welch, G.H. \& Anderson, J.R. Small bowel stricture following abdominal trauma. Postgrad Med J 1985, 61: 1078-1088.

61. Braun, P. \& Dion, Y. Intestinal stenosis following seat belt injury. $J$ Pediatr Surg 1973, 8: 549.

62. Brownstein, E.G. Blunt abdominal trauma simulating Crohn's disease of the terminal ileum. Aust NZ J Surg 1984, 54: 287-289.

63. Wright, J.E. Gallbladder rupture, an isolated seat belt injury. Med J Aust 1976, 1: 785-786.

64. Dryburgh, P.R.\& White, J.A.M. Late obstruction of the intrahepatic common bile duct after seat-belt injury $S A f r$ Med J 1980, 58: 534-535.

65. Freeman, C.P. Isolated pancreatic damage following seat belt injury. Injury 1985, 16: 478-480.

66. Tang, O.T., Mir, A. \& Delamore, I.W. Unusual presentation of seat-belt syndrome. 1974, 4: 750 .

67. Wilkinson, A.J. \& Humphreys, W.G. Seat belt injury to ileostomy. Br Med J 1978, 1: 1249-1250.

68. Christian, M.S. Exemption from compulsory wearing of seat belts - medical indications. $B r \operatorname{Med} J$ 1979, 1: $1411-1412$.

69. Campbell, D.K. \& Austin, R.F. Seat-belt injury: Injury of the abdominal aorta. AJR 1969, 130: 123-124.

70. Clyne, C.A.C. \& Ashbrooke, E.A. Seat-belt aorta: isolated abdominal aortic injury following blunt trauma. Br J Surg 1985, 72: 239.

71. Dajee, H., Richardson, I.W. \& Iype, M.O. Seat belt aorta: Acute dissection and thrombosis of the abdominal aorta. Surgery 1979, 85: 263-267.

72. Dunlop, M.G. Distal arterial emboli following seat belt injury of the aorta. Injury 1986, 17: 370-371.

73. Taylor, T.V. \& Torrance, B. Portal vein thrombosis following a seat-belt injury. $J$ R Coll Surg Edinb 1978, 23: 88-89.

74. Crosby, W.M., King, A.I. \& Stout, L.C. Fetal survival following impact: Improvement with shoulder harness restraint. Am J Obstet Gynecol 1972, 112: 1101. 
75. Rubovits, F.E. Traumatic rupture of the pregnant uterus from 'seat belt' injury. Am J Obstet Gynecol 1964, 90: 828-829.

76. Fakhoury, G.W. \& Gibson, J.R.M. Seat belt hazards in pregnancy. Case report. Br J Obstet Gynaecol 1986, 93: 395-396.

77. Matthews, C.D. Incorrectly used seat belt associated with uterine rupture following vehicular collision. $\mathrm{Am} \mathrm{J}$ Obstet Gynecol 1975, 121: 1115-1116.

78. Rubovits, F.E. Seat belts and pregnancy. JAMA 1964, 189: $172-173$.

79. Crosby, W.M. \& Costiloe, J.P. Safety of lap-belt restraints for pregnant victims of automobile collisions. N Engl J Med 1971, 284: 632.

80. Newman, R.J. Chest wall injuries and the seat belt syndrome. Injury 1984, 16: 110-113.

81. Newman, R.J. \& Jones, S.I. A prospective study of 413 consecutive car occupants with chest injuries. J Trauma 1984, 24: 129.

82. Fletcher, B.D. \& Brogdon, B.G. Seat-belt fractures of the spine and sternum. JAMA 1967, 200: 177-178.

83. Hamilton, J.R., Dearden, C. \& Rutherford, W.H. Myocardial contusion associated with fracture of the sternum: important feature of the seat belt syndrome. Injury 1984, 16: 155-156.

84. Muwanga, L.C., Cole, R.P., Sloan, J.P., Bruce, E., Dove, A.F.\& Dave, S.H. Cardiac contusion in patients wearing seat belts. Injury 1986, 17: 37-39.
85. Richardson, J.D., Grover, F.L. \& Trinkle, J.K. Early operative management of isolated sternal fractures $J$ Trauma 1975, 15: 156.

86. Eastwood, D.S. Subcutaneous rupture of the breast: A seat-belt injury. Br J Surg 1972, 59: 491-492.

87. Dawes, R.F.H., Smallwood, J.A. \& Taylor, I. Seat belt injury to the female breast. Br J Surg 1986, 73: 106-107.

88. Murday, A.J. Seat belt injury of the breast - a case report. Injury 1982, 14: 276-277.

89. Pennes, D.R. \& Phillips, W.A. Auto seat restraint soft-tissue injury. (Letter). AJR 1987, 148: 458.

90. Wallis, M., Todd, I. \& Aber, C.P. Pacemaker discomfort induced by the wearing of seat belts. Postgrad Med J 1985, 61: 305-306.

91. Kelley, J. Purtscher's retinopathy related to chest compression by safety belts. Am J Ophthalmol 1972, 74: $278-283$.

92. Hoare, G.W. Traumatic retinal angiopathy resulting from chest compression by safety belts. $\mathrm{Br} J$ Ophthalmol 1970, 54: 667-669.

93. Wexler, L. \& Silverman, J. Traumatic rupture of the innominate artery. A seat belt injury. $N$ Engl J Med 1970, 282: $1186-1187$. 